\title{
Does Title III of the Americans with Disabilities Act Regulate Insurance?
}

\author{
Luke A. Sobota†
}

Congress enacted the Americans With Disabilities Act ${ }^{1}$ ("ADA") in 1991 to provide a "comprehensive national mandate for the elimination of discrimination against individuals with disabilities." The ADA has led a number of courts to question whether its mandate requires the insurance industry to alter its existing coverage practices toward people with disabilities: how far does the ADA's premise of eliminating discrimination extend with regard to the insurance industry?

While the ADA's Title V purports to leave insurance regulation with the states, several plaintiffs have sued their employers, insurers, and health plan administrators, alleging that the use of disability-based classifications in insurance pricing and underwriting violates the ADA. The plaintiffs point to Title III, which prohibits discrimination against disabled people in the "full and equal enjoyment" of the goods and services of "any place of public accommodations."

In the face of the ADA's textual ambiguity, courts have developed competing interpretations of the ADA. Some hold that Title III of the ADA should not be read to cover the substantive terms of insurance. These courts define "public accommodations" as physical entities and interpret Title III's general antidiscrimination provision to require only access to these physical places. Others hold that Title III covers nonphysical entities, and requires that access-physical or not-to entities be nondiscriminatory. Some courts go farther, holding that Title III regulates the actual substance of the policies that insurers offer. Because states currently permit disability-based underwriting practices, these courts must determine if the ADA's promise of "equality" between the disabled and the nondisabled mandates the elimination of disability-based classifications in insurance.

$\dagger$ B.A. 1996, Pomona College; J.D. Candidate 1999, The University of Chicago.

142 USC $\$ \$ 12101-12213$ (1994).

2 Id $\S 12101(b)(1)$.

${ }^{3}$ Id $\S$ 12182(a). 
Without addressing the issue of whether state insurance laws relating to disabled individuals and disability-based classifications should be supplemented by federal legislation, this Comment argues that Title III is designed not to regulate the terms of insurance but merely to require physical access to public accommodations. Part I of this Comment provides an overview of the regulatory framework of insurance and summarizes the ADA provisions pertaining to insurance. Part II discusses the courts' conflicting interpretations of the scope of Title III as it relates to insurance. Part III offers an alternative means of interpreting the ADA that focuses on the ADA's text, legislative history, and purpose; the Part concludes that Title III does not cover the substance of the goods and services offered by "public accommodations" and consequently does not cover the substance of insurance.

\section{OVERVIEW}

A. Insurance Regulation

In the 1930s, Blue Cross developed America's first large-scale health insurance program in which people could pool funds and thereby manage their risks of illness. ${ }^{4}$ Today, risk management is central to our health care system. Recent estimates suggest that at any given time 83 percent of Americans rely on some form of insurance to cover the costs of their health care, and that over a two-year period only 4.8 percent of the population does not at some point participate in a health insurance program. ${ }^{5}$

The insurance industry is regulated primarily by the states, most often according to statutes based upon model legislation drafted by the National Association of Insurance Commissioners ("NAIC"). ${ }^{6}$ Under the state-regulated system, insurers may legally base coverage and pricing decisions on actuarially sound

\footnotetext{
4 See John V. Jacobi, The Ends of Health Insurance, 30 UC Davis L Rev 311, 316 (1997).

${ }^{5}$ See John Holahan, et al, A Shifting Picture of Health Insurance Coverage, 14 Health Aff 253, 255 (1995) (finding that, in 1993, almost 17 percent of Americans had no insurance). Compare Robert L. Bennefield, Who Loses Coverage and for How Long?, US Census Bureau Current Population Reports No P70-54 1 (May 1996) (indicating that about sixtysix million people, or 27 percent of the United States population, lacked health insurance for at least one month during the study's twenty-eight month period from 1992-94).

${ }^{6}$ See 4 NAIC Model Laws, Regulations and Guidelines, Unfair Trade Practices Act (1997). See also Nancy Perkins, Prohibiting the Use of the Human Immunodeficiency Virus Antibody Test by Employers and Insurers, 25 Harv J Leg 275, 289 (1988) (noting that "[s]ince 1960 all fifty states and the District of Columbia have maintained regulations that embody provisions of NAIC's Unfair Trade Practices Act").
} 
risk classifications. Included in these risk classifications are distinctions based on disabilities. ${ }^{7}$ In general, risk classifications permit insurers to spread health risks among a diverse group of people while charging each group member a premium commensurate with his or her level of risk. For example, a person with Acquired Immunodeficiency Syndrome ("AIDS") may be charged more for life insurance than a person without that disability. Similarly, insurance plans with set premiums (for example, employer-offered benefit plans) often exclude or limit certain types of coverage. $^{8}$

Prior to the enactment of the ADA, all fifty states had statutes, based upon the NAIC's draft model legislation, ${ }^{9}$ prohibiting insurers from " $[\mathrm{m}]$ aking or permitting any unfair discrimination between individuals of the same class and of essentially the same hazard."10 These statutes guarantee equality based on risk classification. For example, an insurer cannot differentiate between two individuals with similar actuarial risk profiles when the insurer writes a life insurance policy. ${ }^{11}$ As such, a person's disability may be actuarially considered by an insurer when determining whether and at what price to offer insurance coverage.

As early as 1973, Congress began responding to increases in health care costs by passing federal legislation to manage health care risk. ${ }^{12}$ This gradual movement towards federalizing some as-

34 NAIC Model Laws, Unfair Trade Practices Act at 880-1, 880-4 (cited in note 6) (prohibiting insurers from "[m]aking or permitting any unfair discrimination between individuals of the same class and of essentially the same hazard in the amount of premium, policy fees or rates charged for any ... health insurance policy").

8 Risk sharing and actuarial classifications result from the insurance industry's nature as a competitive market with limited resources: an increase in coverage or decrease in premiums in one area will result in a decrease in coverage or increase in premiums in another area. If premiums rise, healthy individuals-who subsidize individuals with high risks of illness or death-may exit the insurance pool. Their exit in turn may cause premiums to rise further or reduce the insurer's profitability.

- See 4 NAIC Model Laws, Unfair Trade Practices Act at 880-15-880-18 (cited in note 6).

${ }^{10}$ Id at $880-4$.

${ }^{11} \mathrm{Id}$.

${ }^{12}$ Congressional legislation touching on health care and the insurance industry includes the Rehabilitation Act of 1973, 29 USC $\S 794$ (1994) (prohibiting discrimination based on handicaps in programs receiving federal assistance, including programs affecting the public health and welfare as described under 42 USC $\$ \S 300-300$ aaa13); the Employee Retirement Income Security Act of 1974 ("ERISA"), 29 USC \$§ 1001-1169 (1994 \& Supp 1996) (creating federal regulatory structure for employee benefit plans); the Health Insurance Portability and Accountability Act of 1996 ("HIPAA"), 29 USCA $\S$ 1161-1169 (1985 \& Supp 1998) (allowing certain employees to maintain temporary health care coverage after termination of employment); the Mental Health Parity Act of 1996 ("MHPA"), 42 USCA \& 300gg-5 (Supp 1998) (requiring group health plan providers to place comparable lifetime or annual limits on physical and mental health procedures, provided that certain 
pects of the health insurance industry has resulted in a confused and poorly integrated federal-state framework. Although the McCarran-Ferguson Act of 1945 creates a presumption that congressional acts should be read narrowly in regard to insurance, ${ }^{13}$ the enactment of the ADA has nonetheless drawn state insurance practices into question. It is therefore unclear if and how the ADA alters insurers' ability to use disability-based risk classifications in offering and pricing insurance plans.

\section{B. The ADA}

The ADA's purpose is clear: "to provide a clear and comprehensive national mandate for the elimination of discrimination against individuals with disabilities." ${ }^{14}$ The ADA includes five separate titles, covering employers (Title I) $;{ }^{15}$ public entities (Title II) $;{ }^{16}$ public accommodations (Title III) $;{ }^{17}$ telecommunications (Title IV); ${ }^{18}$ and miscellaneous issues (Title V). ${ }^{19}$

cost-related exemptions are not triggered).

${ }^{13}$ McCarran-Ferguson Act, 15 USC $\S 1012(b)$ (1994) (providing that "no Act of Congress shall be construed to invalidate, impair, or supersede any law enacted by any State for the purpose of regulating the business of insurance . . . unless such Act specifically relates to the business of insurance").

14 42 USC \$ 12101(b)(1).

เs Id $\S \S 12111-17$. Title I prohibits "covered entities" ("an employer . . . [employer's agent, I employment agency, labor organization, or joint labor-management committee") from "participating in a contractual or other arrangement or relationship" that "discriminate[s] against a qualified individual with a disability because of the disability." Id $\S \S$ 12111(2), 12112(b)(2), 12112(a), 12111(5)(A). Title I specifically prohibits an employer from discriminating against a person with disabilities through its relationship with "an organization providing fringe benefits to an employee." 42 USC § 12112(b)(2). This Comment does not address whether Title I covers the terms of employee benefit plans. See $\mathrm{Ni}$ cole Martinson, Inequality Between Disabilities: The Different Treatment of Mental Versus Physical Disabilities in Long-Term Disability Benefit Plans, 50 Baylor L Rev 361 (1998) (citing Title I cases). It is important to note, however, that claims against employers should not be brought under Title III of the ADA. As the Senate Report makes clear, "Title III is not intended to govern any terms and conditions of employment by providers of public accommodations ... employment practices are governed by Title I." The Americans with Disabilities Act of 1989, S Rep No 116, 101st Cong, 1st Sess 58 (1989).

16 42 USC $\$ \$ 12131-65$.

${ }^{17}$ Id $\$ \$ 12162-65$.

${ }^{18} 47$ USC $\$ 225$ (1994) (amending the Communications Act of 1934).

1942 USC $\$ \S 12201-13$. While Titles I-IV create rights of action, courts disagree whether suits can be brought under Title V alone. Compare Doukas $v$ Metropolitan Life Insurance Co, 950 F Supp 422, 425 n 2 (D NH 1996) (finding no indication that Congress intended to create a private right of action under Title V), with Baker $v$ Hartford Life Insurance Co, 1995 US Dist LEXIS 14103, *9-10 (N D IIl) (denying insurer's motion to dismiss a Title $V$ claim because factual issues regarding subterfuge remained). The Senate Report accompanying the ADA explained that Title $V$ "specifies the relationship between this legislation ... and other Federal, State or local laws." S Rep No 116 at 84 (cited in note 15). Since Title V merely clarifies other titles of the ADA, it seems that those titles, themselves, should be used for causes of action. 
Title III of the ADA prohibits "public accommodations" from discriminating against the disabled. Title III's subsection (a) ("general antidiscrimination provision") provides: "No individual shall be discriminated against on the basis of disability in the full and equal enjoyment of the goods, services, facilities, privileges, advantages, or accommodations of any place of public accommodation by any person who owns, leases (or leases to), or operates a place of public accommodation." What constitutes a "public accommodation" is set out in twelve exhaustive categories; ${ }^{21}$ in particular, an "insurance office" is one of the examples used to illustrate the category "service establishments. ${ }^{22}$ Thus, insurance offices are subject to the general antidiscrimination provision of Title III.

The ADA further specifies the meaning of discrimination in Title III's subsection (b)(2) ("specific antidiscrimination provision"). This subsection describes three additional types of discrimination. First, public accommodations may not impose eligibility criteria that tend to "screen out" disabled individuals, unless the public accommodation can prove that the criteria are "necessary" for their operations. ${ }^{23}$ Second, public accommodations must make "reasonable" modifications to their policies and procedures to accommodate the disabled unless doing so would significantly alter their operations. ${ }^{24}$ Third, where necessary, public accommodations must provide auxiliary aids and services for the disabled..$^{25}$ As insurance offices are public accommodations, they

${ }^{20} 42$ USC § 12182(a).

${ }^{21}$ Id $\S 12181(7)(\mathrm{A})-(\mathrm{L})$.

${ }^{22}$ Id $\$ 12181(7)(F)$. The Senate Report explains that the twelve categories of "entities" are exhaustive, but that the illustrative examples are not. S Rep No 116 at 59 (cited in note 15).

${ }^{23}$ Paragraph (i) defines discrimination as

the imposition or application of eligibility criteria that screen out or tend to screen out an individual with a disability or any class of individuals with disabilities ... unless such criteria can be shown to be necessary for the provision of the goods, services, facilities, privileges, advantages, or accommodations being offered.

42 USC § 12182(b)(2)(A)(i) (emphasis added).

24 Paragraph (ii) defines discrimination as

the failure to make reasonable modifications in policies, practices, or procedures, when such modifications are necessary to afford such goods, services, facilities, privileges, advantages, or accommodations to individuals with disabilities, unless the entity can demonstrate that making such modifications would fundamentally alter the nature of such goods, services, facilities, privileges, advantages, or accommodations.

Id $\S 12182(\mathrm{~b})(2)(\mathrm{A})(\mathrm{ii})$ (emphasis added).

${ }^{25}$ Paragraph (iii) defines discrimination as "a failure to take such steps as may be necessary to ensure that no individual with a disability is excluded, denied services, segregated or otherwise treated differently than other individuals because of the absence of aux- 
are subject to the requirements of the specific antidiscrimination provision. It is unclear, however, whether these provisions cover the terms of the policies offered at insurance offices, or just physical access to the office itself.

Title III's relationship to insurance is further informed by the specific reference to insurance in the ADA's "safe harbor" provision included in Title V. Under Title V, Title III may not be read to interfere with insurance underwriting and risk classification procedures that are "based on or not inconsistent with state law."26 The safe harbor provision, in turn, is qualified by a "subterfuge" exception: the safe harbor "shall not be used as a subterfuge to evade the purposes of subchapters I and III of this chapter." ${ }^{27}$

\section{EXISTING JUDICIAL INTERPRETATIONS OF TITLE III}

Disabled individuals have filed numerous Title III suits against insurers, administrators of employee benefit plans, and employers for either (1) denying access to insurance based on the plaintiff's disability or (2) differentiating coverage based on the plaintiff's disability. Courts that have heard these cases agree that, by its plain language, "public accommodation" includes insurance offices. Courts disagree, however, whether Title III requires merely that the disabled be able to physically access insurance offices or instead prohibits insurers from discriminating against people with disabilities in the substance and terms of the insurance plans that the insurer offers. ${ }^{28}$

In particular, federal courts disagree over the definition of "service establishments"; 29 the meaning and import of the words

\footnotetext{
iliary aids and services." Id $\S 12182(\mathrm{~b})(2)(\mathrm{A})(\mathrm{iii})$ (emphasis added).

${ }^{26}$ Id $\S 12201(c)(1)-(2)$ (emphasis added).

${ }^{27}$ Id § 12201(c).

${ }^{23}$ Thus far, Title III cases have dealt only with motions for summary judgment and motions to dismiss; therefore, no court has had to fully address the merits of these insurance claims. The implications of these cases are not trivial, however, as they indicate that disability-based distinctions in pricing health insurance, denials of life insurance based on an existing disability, or limitations in health coverage based on a disability may be discriminatory under Title III. Such holdings may go beyond existing state law requirements and thereby impose a new federal standard. Thus, the cases that hold that Title III regulates the substance and terms of insurance coverage have created a new-and undefinedfederal cause of action for insurance cases.

${ }^{2}$ For interpretations of Title III, 42 USC $\$ 12181(7)(\mathrm{F})$, compare Carparts Distribution Center, Inc $v$ Automotive Wholesaler's Association, 37 F3d 12, 19 (1st Cir 1994) (holding that the plain language in the "service establishment" section, particularly travel service, implies that covered services need not be provided from physical structures), with Parker v Metropolitan Insurance Co, 121 F3d 1006, 1014 (6th Cir 1997) (concluding that "service establishments" are only physical structures), cert denied, Parker $v$ Metropolitan
} 
"service" and "place" in the general antidiscrimination provision; ${ }^{30}$ the plain language of the specific antidiscrimination provisions, ${ }^{31}$ the purpose and meaning of the safe harbor provision; ${ }^{32}$ and the purpose and meaning of the term "subterfuge."133

The disagreement among the federal courts as to the ADA's scope has led to very different outcomes in suits brought pursuant to Title III. Courts holding that Title III does not cover the terms of insurance have dismissed Title III claims where an employer-offered disability policy limited mental health benefits to two years, ${ }^{34}$ an employer-offered health plan denied coverage to

Life Insurance Co, $118 \mathrm{~S} \mathrm{Ct} 871$ (1998); Pallozzi v Allstate Life Insurance Co, 998 F Supp 204, 206 (N D NY 1998) (concluding that Section 12181(7) might cover "insurance offices" but not "insurance companies").

${ }^{30}$ Compare Doe v Mutual of Omaha Insurance, 999 F Supp 1188, 1193 (N D Ill 1998) ("[T] he plain language of Title III's anti-discrimination provisions nowhere indicates that Title III's scope is limited to questions of access."); Doukas $v$ Metropolitan Life Insurance Co, 950 F Supp 422, 426 (D NH 1996) (emphasizing the "broad wording and diversity" of the definition of "discrimination" and finding that "Title III was intended to extend beyond mere access or availability of a good or service"); Kotev $v$ First Colony Life Insurance Co, 927 F Supp 1316, 1321 (C D Cal 1996) (arguing that to limit the scope of Section 12182(a) to only "place[s]" of public accommodation would make Title III applicable to only a few types of disabilities); Baker $v$ Hartford Life Insurance Co, 1995 US Dist LEXIS 14103, *9 (N D III) (holding that insurance is the "service" offered by an insurance office that cannot be denied on the basis of an individual's disability), with Leonard v Israel Discount Bank of New York, 967 F Supp 802, 804 (S D NY 1997) (reading the term "place" as modifying "service" so that only services from physical places are covered under Title III); Pappas $v$ Bethesda Hospital Association, 861 F Supp 616, 620 (S D Ohio 1994) (holding that "place" refers only to physical locations).

${ }^{31}$ Compare Kotev, 927 F Supp at 1322 (holding that the breadth of the three paragraphs encompasses the "discriminatory denial of access to insurance"), with Doukas, 950 F Supp at 426 (holding that the plain meaning of the provision prohibits discrimination in the terms of insurance).

${ }^{32}$ Compare Kotev, 927 F Supp at 1322 (noting that insurer would not need the "safe harbor' provision ... if insurers could never be liable under Title III for conduct such as the discriminatory denial of insurance coverage"), with Ford $v$ Schering-Plough Corp, 145 F3d 601, 611 (3d Cir 1998) (reasoning that the safe harbor subterfuge provision does not require the defendant to provide actuarial data in response to a plaintiff's "mere prima facie allegation"); Leonard, $967 \mathrm{~F}$ Supp at 805 (citing legislative history to support the claim that the ADA was never intended to govern insurance provisions and that the safe harbor provision simply manifested this intention).

${ }^{33}$ Compare Doukas, 950 F Supp at $430-32$ (holding that "subterfuge" simply reinforced the meaning of the safe harbor provision, that specific intent was not required to prove an action was a subterfuge, and that the insurer needed to support its action with either data or prior experience); Baker, 1995 US Dist LEXIS 14103 at *10 ("[E]ven though an insurer may claim to be basing a denial of coverage on actuarial or classification of risk considerations, that claim is not conclusive as the question of whether [the safe harbor provision] is being used as a subterfuge would remain."), with Ford, 145 F3d at 615 (Alito concurring) (following Supreme Court decisions holding that subterfuge has an intent requirement).

${ }^{3}$ Brewster $v$ Cooley Associates/Counseling, 1997 US Dist LEXIS 21433, *1 (D NM); Erwin v Northwestern Mutual Life Insurance Co, 999 F Supp 1227, 1228 (S D Ind 1998); Leonard, 967 F Supp at 806. 
an employee's disabled family members, ${ }^{35}$ and an insurer denied life insurance coverage based on the plaintiff's history of mental illness. ${ }^{36}$ In contrast, courts holding that Title III does cover the substance of insurance have allowed plaintiffs' claims to go forward where a medical reimbursement plan amended its health plan to cap AIDS benefits at $\$ 25,000 ;{ }^{37}$ an insurer denied health coverage because of an applicant's history of seizures; ${ }^{38}$ an insurer denied life insurance to an applicant with a Human Immunodeficiency Virus-positive ("HIV") partner,; ${ }^{39}$ an insurer capped mental disability benefits at two years; ${ }^{40}$ an insurer denied disability insurance because of the applicant's bipolar disorder; ${ }^{41}$ and an insurer capped AIDS health benefits at $\$ 25,000 .{ }^{42}$ In one case, a court granted the plaintiff summary judgment where the insurer charged a higher life insurance premium to an individual with muscular dystrophy. ${ }^{43}$

This Part analyzes how the courts came to such different interpretations regarding Title III's scope and coverage of insurers and the services they offer.

\section{A. Defining the Scope of Title III's}

Antidiscrimination Provisions

Courts addressing Title III insurance claims must first address the broader issue of whether Title III covers merely access to public accommodations or regulates the goods and services they offer.

1. Limiting Title III's protection to physical access.

The general antidiscrimination provision provides: "No individual shall be discriminated against on the basis of disability in the full and equal enjoyment of the goods, services, facilities, privileges, advantages, or accommodations of any place of public accommodation." ${ }^{44}$ The Sixth and Third Circuits have interpreted

${ }^{35}$ Pappas, 861 F Supp at 617.

${ }^{36}$ Pallozzi, 998 F Supp at 205, 207.

${ }^{37}$ Carparts, 37 F3d at 20.

${ }^{38}$ Baker, 1995 US Dist LEXIS 14103 at *10.

${ }^{39}$ Kotev, 927 F Supp at 1321; Cloutier v Prudential Insurance Co of America, 964 F Supp 299, 305 (N D Cal 1997).

${ }^{40}$ Lewis v Aetna Life Insurance Co, 982 F Supp 1158, 1169 (E D Va 1997).

4 Doukas, 950 F Supp at 429.

12 Doe, 999 F Supp at 1190, 1197.

${ }^{43}$ Chabner $v$ United of Omaha Life Insurance Co, 994 F Supp 1185, 1196 (N D Cal 1998).

${ }^{4} 42$ USC § 12182(a). 
the statutory definition of "public accommodation" to include only physical structures. Consequently, these circuits hold that Title III regulates only physical access to-and not the substance of the goods and services offered by places of public accommodation such as insurance offices.

In Parker $v$ Metropolitan Insurance Co ${ }^{45}$ the Sixth Circuit held that "public accommodation" refers to physical places open to the public at large and that Title III regulates merely the availability, not the substance, of the goods and services offered by a public accommodation. ${ }^{46}$ In Parker, the plaintiff sued her employer and the employer's insurance company for discriminatorily capping mental disability benefits at two years, while offering physical disability benefits until age $65 .{ }^{47}$ The court, relying on an earlier decision defining "public accommodation" as a physical place, ${ }^{48}$ held that the employer-offered insurance plan was not a "good or service" offered by a "place" of public accommodation ${ }^{49}$ because "the public cannot enter the office of [the insurer] or [the employer] and obtain the long-term disability policy that plaintiff obtained." ${ }^{n 0}$

Addressing the possibility that the "travel service" illustration might refer to a nonphysical place, since travel agent serv-

4121 F3d 1006 (6th Cir 1997), cert denied, Parker $v$ Metropolitan Life Insurance Co, 118 S Ct 871 (1998).

${ }^{46} 121$ F3d at 1011-12.

${ }^{47}$ Id at 1007.

${ }^{43}$ See Stoutenborough v National Football League, Inc, 59 F3d 580, 582-83 (6th Cir 1995) (dismissing a Title III claim against several television stations and the National Football League, where deaf plaintiff alleged that "black[ing] out" coverage of the Cleveland Brown's football games (that is, permitting only a radio broadcast) prevented him from enjoying the game, because broadcasts do not involve "a place of public accommodation").

49 121 F3d at 1011. The court cited the Department of Justice Regulations that define "place of public accommodation" as "a facility, operated by a private entity, whose operations affect commerce and fall within at least one of the twelve public accommodation categories." Id, citing 28 CFR $\S 36.104$ (1991). The regulations define a "facility," in turn, as "all or any portion of buildings, structures, sites, complexes, equipment, rolling stock or other conveyances, roads, walks, passageways, parking lots, or other real or personal property, including the site where the building, property, structure, or equipment is located." 121 F3d at 1011, citing $28 \mathrm{CFR} \S 36.104$.

${ }^{50} 121 \mathrm{~F} 3 \mathrm{~d}$ at 1011 . The court seems to have augmented the physical nexus test found in Pappas, 861 F Supp at 620 (see text accompanying notes 59-61), by focusing on the availability of the service to the "public" rather than just the individual plaintiff. While the source of this test is unclear, it has serious ramifications. Under it, all employeroffered health insurance provisions would be exempted from the ADA, even if the employee physically entered the office of the insurer. See also Erwin, $999 \mathrm{~F}$ Supp at 1233 (holding that an employer-offered disability benefit plan was not a "public accommodation" under Title III because "[p]laintiff obtained the ... plan as an employee through his employer, rather than as an individual through the insurance sales offices"). 
ices are available over the phone, the Parker court stated: "The clear connotation of the [statute] is that a public accommodation is a physical place. . . . [I]t is likely that Congress simply had no better term than 'service' to describe an office where travel agents provide travel services and a place where shoes are repaired."51 Employing the canon of statutory construction noscitur a sociis, ${ }^{62}$ the court held that "travel service" should be read as a physical establishment consistent with the other illustrations surrounding it. ${ }^{53}$ Parker took no position, however, on whether plaintiffs "must physically enter a public accommodation to bring a suit under Title III as opposed to merely accessing, by some other means, a service or good provided by a public accommodation."54

The Third Circuit reached the same conclusion in Ford $v$ Schering-Plough Corp.$^{55}$ Considering facts similar to those at issue in Parker, the court followed Parker's reasoning, and held that the plain meaning of "public accommodation" is a "place." As such, the court did not allow the plaintiff employee to sue her employer's insurer, because "she had no nexus to [the] insurance office' and thus was not discriminated against in connection with public accommodation."57 According to the Ford court, the terms of the general antidiscrimination provision "are not free-standing concepts but rather all refer to the statutory term 'public accom-

${ }^{51} 121$ F3d at 1014. In Pallozzi, 998 F Supp at 206, the insurer argued: "Congress chose to include in the list of places of public accommodations an 'insurance office,' which is open to the public, but not an 'insurance company, which is where the underwriting decisions are made." Under this interpretation, which the court seemed to credit, Title III does not cover the terms of an insurance plan or policy. See id at 207 (holding that "Title III of the ADA was not intended to reach the underwriting practices of insurance companies").

${ }^{52}$ "The doctrine of noscitur $a$ sociis instructs that ' $a$. . . term is interpreted within the context of the accompanying words to avoid giving unintended breadth to the Acts of Congress." Parker, 121 F3d at 1014, quoting Kurinsky v United States, 33 F3d 594, 597 (6th Cir 1994). See also Black's Law Dictionary 1060 (West 6th ed 1990).

${ }^{53} 121$ F3d at 1014. See also Ford, 145 F3d at 614 ("The litany of terms, including 'auditorium,' 'bakery,' 'aundromat,' 'museum,' 'park,' 'nursery,' 'food bank,' and 'gymnasium [ ]' refer to places with resources utilized by physical access. Pursuant to the doctrine of noscitur a sociis, the terms that the First Circuit finds ambiguous should be interpreted by reference to the accompanying words of the statute 'to avoid the giving of unintended breadth to the Acts of Congress.") (citations omitted).

st 121 F3d at $1011 \mathrm{n} 3$.

ss 145 F3d 601 (3d Cir 1998).

${ }^{56}$ Id at 612-13.

${ }^{57}$ Id. It should be noted that under both Ford and Parker, administrators of employee benefit plans cannot be sued under Title III because the policies they offer are not available to the "public" at large and the employees do not physically access the administrator's office. 
modation' and thus to what these places of public accommodation provide. ${ }^{\$ 58}$

As a corollary to their conclusion that Title III covers only physical access to public accommodations, several courts have determined that Title III does not cover the substance of insurance. For example, in Pappas $v$ Bethesda Hospital Association, ${ }^{59}$ the court read the definition of "public accommodation" as purely physical in light of the general antidiscrimination provision's use of the word "place." Pappas held that "the references throughout Title III make it clear that its scope is limited to the discrimination in the provisions of goods, services, facilities, privileges, advantages or accommodations based on a disabled person's physical ability to make use of those goods, services, etc." ${ }^{160}$ Thus, the Pappas court dismissed plaintiff's Title III claim against her employer and its administrator of employee benefits for denying her family health insurance since the claim had "nothing to do with an inability to make physical use of the services of a place of public accommodation."

In Lenox $v$ Healthwise of Kentucky, $L t d,{ }^{62}$ the Sixth Circuit reinforced this physical access only reading by citing Department of Justice Regulations interpreting the ADA: "The purpose of the ADA's public accommodations requirements is to ensure accessibility to the goods offered by a public accommodation, not to alter the nature or mix of the goods." ${ }^{.63}$ In Lenox, the circuit court affirmed the district court's dismissal of an employee's Title III claim against her insurer for discriminating by not providing coverage for heart transplants while providing coverage for other transplants. ${ }^{64}$ The Lenox court held that this claim, which related to the "mix of goods and services offered by an insurance company," did not "demonstrate the existence of any barrier to her accessing Healthwise's physical facility ... . [or to] taking advan-

Id at 613 .

59 861 F Supp 616 (S D Ohio 1994).

${ }^{60}$ Id at 620 (emphasis added).

${ }^{61}$ Id. See also Leonard, 967 F Supp at 804 (reading the general antidiscrimination provision's "services" to be "clearly [ ] modified and limited by the words "of any place of public accommodation"').

62 149 F3d 453 (6th Cir 1998).

${ }^{63}$ Id at 456, citing 28 CFR pt 36, app B, $\$ 36.307$ (1998) ("In other words, a bookstore, for example, must make its facilities and sales operations accessible to individuals with disabilities, but is not required to stock Brailled or large print books. Similarly, a video store must make its facilities and rental operations accessible, but is not required to stock closed-captioned video tapes.").

at 149 F3d at 454 . 
tage of the goods and services that are available . . . at Healthwise's physical facility."

Thus, these courts hold (1) that employer-offered benefit plans are not covered by Title III since employees cannot physically access the administrator's office and (2) that Title III does not cover the terms of insurance because Title III does not regulate the goods and services offered by public accommodations.

2. Extending Title III's protections beyond mere access to physical structures.

Other courts, relying on two different theories, have used the general and specific antidiscrimination provisions to extend Title III's coverage beyond mere physical access. First, because the definition and illustrations of "public accommodation" include nonphysical structures, some courts have read the provision to indicate that Title III's prohibition on discrimination extends beyond mere physical access to public accommodations. ${ }^{66}$ Second, because language contained in Title III's general and specific antidiscrimination provisions is quite broad, some courts have read this language to suggest that Title III is more concerned with the substance of the goods and services that public accommodations actually provide rather than the mere opportunity to access them.

a) Title III extends to service transactions outside of physical structures. The first argument looks exclusively at how Congress defined public accommodation to decide whether Title III covers more than access to physical structures. In Carparts Distribution Center, Inc $v$ Automotive Wholesaler's Association, ${ }^{67}$ the First Circuit held that Title III prohibits more than discrimination in access to physical structures since "public accommodation" refers to more than physical buildings. The plaintiff in Carparts, a member of a self-funded medical reimbursement plan, sued the association and its administrator under Title III for discriminating against individuals with AIDS. The association had amended its plan to cap AIDS-related benefits at $\$ 25,000$ lifetime while all other illnesses were capped at $\$ 1$ million lifetime. The court first reviewed the "service establishment" definition of "public accommodation." Concentrating on "travel service," which accompa-

${ }^{65}$ Id at 457.

${ }^{66}$ This reading also expands Title III to include administrators of employer-offered benefit plans, which are not covered under the physical-only definition of "public accommodation."

${ }^{67} 37$ F3d 12 (1st Cir 1994).

${ }^{63}$ Id at 19. 
nies "insurance office" as one of the fifteen illustrations of service establishments, ${ }^{69}$ the court concluded, "Congress clearly contemplated that 'service establishments' include providers of services which do not require a person to physically enter an actual physical structure." The court reasoned that Congress could not have intended the "irrational" result of extending ADA protection to those who physically enter an office to purchase a service, but not to those who purchase the same service by mail or by telephone. ${ }^{71}$

After holding that "public accommodations" could be nonphysical, the Carparts court turned to the scope of Title III. In dicta, the court opined:

As a matter of bare language, one could spend some time arguing about whether [the general antidiscrimination provision] is intended merely to provide access to whatever product or service the subject entity may offer, or is intended in addition to shape and control which products and services may be offered. ${ }^{72}$

In particular, the court noted that nothing in the legislative history "explicitly precludes an extension of the statute to the substance of what is being offered," ${ }^{, 73}$ but it also acknowledged that the Committee Reports on Title III could be characterized as "primarily concerned with ... physical access to a place of public accommodation or something analogous, such as access provided through telephone lines, messengers, or some other medium.."74 Although raising this interpretive issue, the court declined to resolve it and limited its holding to the possibility that Title III may cover more than the mere denial of physical access to the public accommodation.

b) Title III reaches the substance of insurance claims. Other courts, however, have not so limited themselves and have con-

42 USC $\S 12181(7)(\mathrm{F})$.

io 37 F3d at 19.

"Id. Carparts's definition of "public accommodation" was adopted in Kotev, 927 F Supp at 1321-22. Kotev rejected the notion that Title III covers only "access to physical structures" because such a narrow interpretation would, among other things, "bar discrimination against only some of the categories of persons explicitly protected by the ADA." Id at 1321. The court noted, for example, that "many persons who do not suffer from a physical handicap but are explicitly protected by Title III could bring a Title III claim only if the public accommodation took affirmative steps to block such persons' physical access." Id at 1322. Note that the Parker court took no position on this issue. See text accompanying note 54 .

$7237 \mathrm{~F} 3 \mathrm{~d}$ at 19 (emphasis added).

${ }^{73}$ Id at 20 (emphasis added).

${ }^{3}$ Id. 
strued the broad language found in Title III's general ${ }^{75}$ and specific $^{76}$ antidiscrimination provisions to regulate the availability and terms of insurance plans. Examining the general antidiscrimination provision, the court in Cloutier $v$ Prudential Insurance Co of America ${ }^{77}$ permitted a Title III claim against an insurer that denied life insurance because of the applicant's physical relationship with a person with AIDS. The court explained: "Interpreting Title III to prohibit only physical barriers to the access of 'facilities' would dispense with the language mandating equal opportunity to 'participate in or benefit from' the 'goods,' 'services,' 'privileges,' and 'advantages' of a commercial transaction." 78

Another court has reasoned that the general and specific antidiscrimination provisions demonstrate that Title III regulates insurance. In Doukas $v$ Metropolitan Life Insurance Co ${ }^{79}$ the plaintiff sued based on a denial of mortgage disability insurance because of her medical history. The court held that her claim was consistent with alleging that "(1) she was denied the opportunity to benefit from [the insurer's] insurance products . . . or (2) by denying [plaintiff's] application for insurance, [the insurer] provided her with a good or service different from that provided to others. ${ }^{\prime 80}$ While Doukas dealt with denial of coverage, Doe v Mutual of Omaha Insurance ${ }^{81}$ dealt with terms of coverage and held that a health insurer's cap on AIDS coverage "could alternately be viewed as a discriminatory denial of the 'full and equal enjoyment' of goods or a service; as a discriminatory denial of an equal

\footnotetext{
${ }^{75}$ "No individual shall be discriminated against on the basis of disability in the full and equal enjoyment of the goods, services, facilities, privileges, advantages, or accommodations of any place of public accommodation by any person who owns, leases (or leases to), or operates a place of public accommodation." 42 USC $\S 12182$ (a).

${ }^{76}$ Id $\$ 12182(\mathrm{~b})(2)(\mathrm{A})(\mathrm{i})$-(iii). See notes $23-25$ for the statutory language.

" 964 F Supp 299 (N D Cal 1997).

${ }^{78}$ Id at 302 , quoting 42 USC $\$ 12182(a)$. This reading, based upon the canon of statutory construction dictating that courts should construe a statute to avoid rendering any parts of it superfluous, finds support in Congress's repeated use of the same language throughout the statute, suggesting "the importance of considering each noun in the series." 964 F Supp at $302 \&$ n 2. See also Doukas, 950 F Supp at 426 (emphasizing the "broad wording and diversity" of the definition of discrimination and finding that "Title III was intended to extend beyond mere access or availability of a good or service"); Doe, 999 F Supp at 1193 ("[T]he plain language of Title III's antidiscrimination provisions nowhere indicates that Title III's scope is limited to questions of access."). The Supreme Court has favored this type of construction. See Astoria Federal Savings \& Loan Association $v$ Solimino, 501 US 104, 112 (1991) (citing the maxim that courts should interpret statutes "so as to avoid rendering superfluous any parts thereof").

${ }^{79} 950$ F Supp 422 (D NH 1996).

${ }^{80}$ Id at 426 (emphasis added) (citation omitted).

${ }^{81} 999$ F Supp 1188 (N D Ill 1998).
} 
opportunity to benefit from goods or a service; as the discriminatory denial of an opportunity to benefit from goods or a service; or as the provision of goods or a service different from that provided to others." ${ }^{\prime 2}$

\section{B. Confusion Over the Safe Harbor Provision}

The safe harbor provision of Title $V$ further confuses the debate about whether Title III regulates the substance of insurance plans. Paragraphs (1) and (2) of the safe harbor provision state that Title III "shall not be construed to prohibit or restrict" an insurer from underwriting, classifying, or administering risks "that are based on or not inconsistent with State law. ${ }^{~}{ }^{83}$ However, a defendant cannot use this safe harbor "as a subterfuge to evade the purposes [of the ADA].".84

Some courts cite the safe harbor provision to support their position that Title III does not regulate the substance of insurance plans. Others cite the safe harbor provision as proof that Title III does regulate the substance of insurance plans. Neither camp, however, offers a comprehensive analysis of the safe harbor's purpose and scope.

\section{A safe "safe harbor."}

Some courts view the safe harbor provision as explicitly carving out insurance from the ADA's scope. Leonard $v$ Israel Discount Bank of New York, ${ }^{85}$ concluded that the "ADA does not, nor was it ever intended to regulate the business of insurance, and for that reason it includes an explicit 'Safe Harbor' provision shielding traditional insurance risk classification practices from regulation under the ADA. ${ }^{386}$ According to Leonard, the safe har-

82 Id at 1193. See also Kotev, 927 F Supp at 1321-22 (holding that the "broadly stated

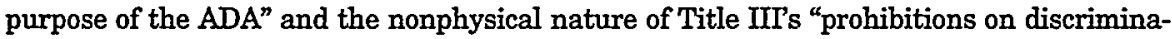
tion" indicate that the substance of insurance policies are covered).

The safe harbor provision explains that the ADA "shall not be construed to prohibit or restrict . . . an insurer, hospital or medical service company, health maintenance organization, or any agent, or entity that administers benefit plans, or similar organizations from underwriting risks, classifying risks, or administering such risks that are based on or not inconsistent with State law." 42 USC \$ 12201(c)(1).

8s "Paragraphs (1) [and] (2) shall not be used as a subterfuge to evade the purposes of subchapter[s] I and III of this chapter." Id § 12201(c).

${ }^{85} 967$ F Supp 802 (S D NY 1997).

${ }^{86}$ Id at 805 . The court in Ford made a broader policy argument against requiring an insurer to provide actuarial data after a prima facie Title III showing by a plaintiff:

[W]e will not construe section 501 (c) to require a seismic shift in the insurance business, namely requiring insurers to justify their coverage plans in court after a mere allegation by a plaintiff. . . . [R]equiring insurers to justify their coverage plans ele- 
bor simply reinforces the conclusion that Title III does not regulate insurance.

The Ford court, relying on the subterfuge provision of the safe harbor, went into more detail. The plaintiff in that case argued that, after a prima facie showing of discrimination, the safe harbor provision requires the defendant-insurer to present actuarial data to demonstrate that its plan is not a "subterfuge" of the ADA's purposes. The court, however, rejected this argument, defining "subterfuge" as a "scheme, plan, strategem, or artifice of evasion." Ford's interpretation of "subterfuge," relying on Supreme Court interpretations ${ }^{88}$ of the "subterfuge" provision found in the Age Discrimination in Employment Act, ${ }^{89}$ led it to conclude there is no "subterfuge" of Title III unless an insurance plan is adopted specifically "to evade the purposes of the ADA.

vates this court to the position of super-actuary. This court is clearly not equipped to become the watchdog of the insurance business, and it is unclear exactly what actuarial analysis the defendants would have to produce to disprove the charge of "subterfuge[.]"

145 F3d at 612 (citations omitted).

${ }_{87} 145$ F3d at 611 (citations omitted).

${ }^{83}$ See Public Employees Retirement System of Ohio v Betts, 492 US 158, 167 (1989); United Air Lines, Inc v McMann, 434 US 192, 203 (1977). See text accompanying notes 144-53 for a discussion of these holdings.

${ }^{89} 29$ USC § 623(f)(2) (1976) ("It shall not be unlawful for an employer, employment agency, or labor organization . . . to observe the terms of a bona fide seniority system or any bona fide employee benefit plan such as retirement, pension, or insurance plan, which is not a subterfuge to evade the purposes of this chapter.").

${ }^{90} 145$ F3d at 611 . Some have added that "subterfuge" requires "intent." See Krauel $v$ Iowa Methodist Medical Center, 95 F3d 674, 678-79 (8th Cir 1996) (defining, in a Title I claim, "subterfuge" as the intentional use of Section 12201(c) to discriminate in a nonfringe benefit aspect of the employment relationship); Ford, 145 F3d at 615 (Alito concurring) (finding an "intent" requirement). These interpretations are supported by Betts, 492 US at 167 (interpreting "subterfuge" in the Age Discrimination in Employment Act ("ADEA") to require an intent to evade a nonfringe benefit area of the ADEA); Modderno $v$ King, 82 F3d 1059, 1065 (DC Cir 1996) (holding that the Betts definition of subterfuge applies to Section 12201(c) of the ADA because "when Congress chose the term 'subterfuge' for the insurance safe-harbor of the ADA, it was on full alert as to what the Court understood the word to mean and possessed (obviously) a full grasp of linguistic devices available to avoid that meaning”), cert denied, 117 S Ct 772 (1997). The Supreme Court has relied on this canon of construction before when interpreting ambiguous ADA provisions, most recently to hold that HIV infection is a "disability" under the ADA even when the infection has not reached the "symptomatic phase." Bragdon v Abbott, 118 S Ct 2196, 2208 (1998) ("When administrative and judicial interpretations have settled the meaning of an existing statutory provision, repetition of the same language in a new statute indicates, as a general matter, the intent to incorporate its administrative and judicial interpretations as well."). Nonetheless, opinions interpreting the "subterfuge" provision as requiring the insurance plan to have been adopted after the passage of the ADA and the insurance company to have a specific intent to violate Title III seem to contradict the ADA's legislative history. For a further analysis of this discrepancy, see Part III.B.2. 
Courts using this construction of the safe harbor provision buttress their arguments with the McCarran-Ferguson Act of $1945,{ }^{91}$ which provides that federal statutes should be construed not to interfere with the states' insurance laws unless the legislation expressly regulates the insurance industry. ${ }^{92}$ The Ford court explained, "The ADA does not 'specifically relate[ ] to the business of insurance[,]' ... and we will not construe [the safe harbor provision] to require a seismic shift in the insurance business, namely requiring insurers to justify their coverage plans in court after a mere allegation by a plaintiff." ${ }^{33}$ The court went on to question the competence of courts to actuarially assess insurance plans: "This court is clearly not equipped to become the watchdog of the insurance business, and it is unclear exactly what actuarial analysis the defendants would have to produce to disprove the charge of 'subterfuge. ${ }^{m 94}$

Based on this reading of the safe harbor provision, or the conclusion that Title III does not cover the terms of insurance, several courts have dismissed Title III insurance cases at the summary judgment stage. ${ }^{95}$

\section{An unsafe "safe harbor."}

Courts holding that Title III covers the substance of insurance have read the safe harbor provision differently. Although these courts have reached varying conclusions about the precise meaning of the safe harbor's "not inconsistent with state law" and "subterfuge" provisions, they nonetheless conclude that the safe harbor provision does not exempt the substance of insurance plans from regulation under Title III.

${ }_{91} 15$ USC § 1012(b) (1945) (providing that "no Act of Congress shall be construed to invalidate, impair, or supersede any law enacted by any State for the purpose of regulating the business of insurance ... unless such Act specifically relates to the business of insurance").

2 See Leonard, 967 F Supp at 805. It is unclear, however, whether the ADA's language should be construed as "specifically" relating to insurance. See Doe, 999 F Supp at 1195-96 (rejecting insurer's argument that the McCarran-Ferguson Act prohibits application of the ADA to insurance practices, the court found that (a) the ADA reference to "insurance office" and the safe harbor provision provide the "specific indicia of [the Act's] intent" to regulate insurance and that (b) there was no showing that the application of Title III in Illinois would "invalidate, impair, or supersede" any Illinois insurance law). Nonetheless, the purpose of the Act to limit federal intrusion on the state-regulated insurance industry militates against an expansive reading of the $\mathrm{ADA}$ as it relates to insurance.

${ }^{23} 145$ F3d at 611-12, quoting 15 USC $\S 1012(\mathrm{~b})$.

\%4 145 F3d at 612 .

${ }^{96}$ See notes 34-36 and accompanying text. 
For example, in Doukas, the court found ambiguous the safe harbor's requirement that it be used only when insurance practices are "not inconsistent with state law." Relying on a portion of the ADA Senate Report ${ }^{97}$ in order to determine what the phrase was intended to mean, the court held that the safe harbor provision requires that "the insurance practice [ ] either be based on actuarial data or on the company's actual or reasonably anticipated experience relating to the risk involved." effectively requires federal courts to evaluate insurance plans to determine if they are based on sound actuarial practice. The court added that, even if the insurance action received safe harbor protection, compliance with state law could not be used as a "subterfuge" to evade the ADA's purposes. ${ }^{99}$ Without defining "subterfuge," the court held that a plaintiff need not prove that defendant "inten[ded]" 100 to evade the purposes of the ADA. Therefore, a plan developed before the ADA's enactment-and hence without any "intent" to evade-could nonetheless be a "subterfuge"101 of Title III if the plan was not consistent with sound actuarial practice. ${ }^{102}$

Reaching a similar result, but using a different analysis, the Cloutier court held that because the insurer met state law requirements, its practices were "not inconsistent with state law." "103 Relying on the ADA's legislative history, ${ }^{104}$ the Cloutier court concluded that the "subterfuge" language was "intended ... to assure that an insurer's 'refusal, or limitation [of coverage], or rate differential is based on sound actuarial principles, or is related to actual or reasonably anticipated experience."'105 Under Cloutier, even if the insurer complies with state law, the federal court

${ }^{96} 950 \mathrm{~F}$ Supp at 428 . See also Chabner, $994 \mathrm{~F}$ Supp at 1196 ( ${ }^{\alpha}[\mathrm{A}]$ basis in actuarial data is required under both the actuarial principles and the experience prongs.").

${ }^{97} \mathrm{~S}$ Rep No 116 at 85-86 (cited in note 15).

${ }^{93} 950$ F Supp at $428-29$.

${ }^{99}$ Id at 430 .

${ }^{100}$ For statements that "subterfuge" does not imply that a court find "malicious intent" on the insurer's part, see 136 Cong Rec H 4624 (daily ed July 12, 1990) (statement of Rep Edwards); 136 Cong Rec S 9697 (daily ed July 13, 1990) (statement of Sen Kennedy).

${ }^{101}$ See Americans with Disabilities Act of 1990, HR Rep No 485(II), 101st Cong, 2d Sess 136 (1990) (Section 12201(c) may not be used to evade Titles I, II, or III "regardless of the date [of] an insurance plan or employer benefit plan.").

${ }^{102}$ Doukas, 950 F Supp at $430-32$.

${ }^{103} 964$ F Supp at 303, quoting 42 USC $\S 12201$ (c)(1).

${ }^{10} \mathrm{HR}$ Rep No 485(III) at 71 (cited in note 101). See Part III.B.2 for discussion of the House Judiciary Report.

${ }^{105} 964 \mathrm{~F}$ Supp at 304, quoting HR Rep No 485(III) at 71 (cited in note 101). 
must determine if the insurance practices are actuarially justified or based on reasonable experience. ${ }^{106}$

Thus, despite their different interpretations of the ADA's text, the end result of both cases is almost indistinguishable, as both Cloutier's definition of subterfuge and Doukas's reading of "not inconsistent with state law" lead to ADA coverage of the substance of insurance. Consequently, the courts holding that Title III covers the terms of insurance have allowed cases to move beyond the summary judgment stage to determine if the insurer's action was consistent with state law, based on actuarial data or accepted risk classifications, or based on actual or reasonably anticipated experience. ${ }^{107}$

\section{A PROPOSAL FOR INTERPRETING TITLE III}

Since an insurer is a "public accommodation," its service would appear to be covered by the general antidiscrimination provision, which guarantees the "full and equal enjoyment of the goods, services, facilities, privileges, advantages, or accommodations of any place of public accommodations." ${ }^{108}$ But finding that the service of an insurer is covered does not answer how or to what extent the provision regulates insurance. Does it mean that no disability-based classifications can be used in underwriting the policy? Does it mean that no disabled person can be denied coverage? Or does it mean that a disabled individual must have the same opportunity as a nondisabled person to apply for insurance?

This Part seeks to offer a more comprehensive analysis of both Title III and the safe harbor provision by analyzing the ADA's text, legislative history, and purpose. It concludes that Title III does not cover the substance of the goods and services offered by a "public accommodation" and that the safe harbor provision, properly constructed, clarifies and reinforces this interpretation.

A. Defining the Scope of Title III

1. Construing "public accommodations."

As discussed in Part II.A.2, courts holding that Title III extends beyond mere access to physical structures have pointed to

\footnotetext{
${ }^{106} 964$ F Supp at 304.

${ }^{107}$ See text accompanying notes 37-43.

${ }^{108} 42$ USC § 12182(a).
} 
the "travel service" illustration of a "service establishment," explaining that the travel service illustration demonstrates Congress's intention to expand the definition of "public accommodation" beyond physical entities. ${ }^{109}$ The ADA's legislative history challenges this argument, however, and indicates that Congress did not intend for "public accommodations" to extend beyond physical entities open to the public at large.

Before the ADA's enactment, many disabled people led social lives marked by isolation and seclusion. ${ }^{110}$ To provide disabled people full access to their communities, the Senate Committee on Labor and Human Resources expressed the "need to define places of public accommodation[s] to include all places open to the public, not simply restaurants, hotels, and places of entertainment ... because discrimination against people with disabilities is not limited to specific categories of public accommodations."111 Congress's desire to incorporate all types of publicly used buildings in the definition of "public accommodation" does not lead to the conclusion, espoused in Carparts, that Congress sought to define "public accommodation" as nonphysical. Rather, the addition of "service establishment" as a category of public accommodation simply ensures that all privately operated facilities open to the public are covered under the ADA. ${ }^{112}$

In addition, to interpret "public accommodation" to include nonphysical entities creates textual incongruities when the interpretation is considered in the context of Title III's general antidiscrimination provision. Carparts's holding extended the ADA's coverage to those cases where establishments fail to accommo-

${ }^{109}$ See, for example, Carparts, 37 F3d at 19.

${ }^{110} \mathrm{~S}$ Rep No 116 at 10-11 (cited in note 15). Witnesses appearing before the Committee identified three causes for disabled persons not frequenting "places of public accommodations and stores": (1) they "do not feel that they are welcome or can participate safely" in public accommodations; (2) they are "self-conscious about their disability" ("stemming from degrading experiences"); and (3) they are effectively denied access through architectural, communication, and transportation barriers. Id.

${ }^{11}$ Id. The Committee cited testimony by Professor Robert Burgdorf, Jr.:

[I]t makes no sense to bar discrimination against people with disabilities in theaters, restaurants, or places of entertainment but not in regard to such important things as doctors' offices. It makes no sense for a law to say that people with disabilities cannot be discriminated against if they want to buy a pastrami sandwich at the local deli but that they can be discriminated against next door at the pharmacy where they need to fill a prescription. There is no sense to that distinction.

Id.

${ }^{112}$ Id at 58. The kinds of businesses included in the ADA's "service establishment" category were not included in Title II of the Civil Rights Act of 1964, nor were they covered by the Rehabilitation Act of 1973. One express purpose of the drafters of the ADA was to remedy these omissions. See id at 11, 58. 
date disabled individuals with nonphysical modes of access to its goods or services. ${ }^{113}$ The problem with the Carparts analysis is demonstrated by substituting Carparts's nonphysical definition of public accommodation in the text of the general antidiscrimination provision. After substitution, the provision would read: "No individual shall be discriminated against on the basis of disability in the full and equal enjoyment of . . . any place of nonphysical entities." The provision is rendered nonsensical, exposing the difficulty of determining the scope of Title III by using the definition of "public accommodation."

The Carparts court erred because it used an illustration of "public accommodation" to justify expanding the scope of Title III. The connection between the two is highly attenuated. If Congress intended to cover the substance of services with Title III, it likely would have taken the simple approach of stating its intention explicitly rather than hiding it in one of the fifteen illustrations of one of the twelve categories defining "public accommodations." For this reason, the analysis that public accommodation can be nonphysical does little to advance the argument that Title III regulates the nature or mix of the goods and services offered by public accommodations. A better reading interprets public accommodation to include only physical structures open to the public.

2. Interpreting the scope of the general and specific antidiscrimination provisions.

The plain text of the general ${ }^{114}$ and specific ${ }^{115}$ antidiscrimination provisions provides a strong basis for arguing that Title III reaches the substance of insurance. However, a close examination of the ADA's text and history undermine this expansive reading. The plain meaning of "place" found in the general antidiscrimination provision connotes a physical structure. ${ }^{116}$ The Department of Justice Regulations interpreting the ADA reinforce this conclusion by defining "place" as a "facility" or "all or any portion of buildings, structures, sites, complexes, equipment, rolling stock or other conveyances, roads, walks, passageways, parking lots, or

\footnotetext{
${ }^{113}$ But see Parker, 121 F3d at 1011 n 3 (taking no position on whether "a plaintiff must physically enter a public accommodation to bring suit under Title III as opposed to merely accessing, by some other means, a service or good provided by a public accommodation").

${ }^{114} 42$ USC \& 12182(a).

${ }^{115}$ Id $\S 12182(\mathrm{~b})(2)(\mathrm{A})(\mathrm{i})$-(iii). See notes $23-25$ for the text of the specific antidiscrimination provision.

${ }^{126}$ See Leonard, 967 F Supp at 804; Pappas, 861 F Supp at 620.
} 
other real or personal property." 117 Because all of its terms are modified by the term "place," the general antidiscrimination provision's call for "full and equal enjoyment" likely only extends physical access to the structure where the goods and services are offered: Title III regulates access to the place of the "goods and services," not the goods and services themselves.

However, unlike the general antidiscrimination provision, the three subparagraphs of the specific antidiscrimination provision are not limited by the term "place." The language of subparagraph (i), for example, could be read such that disabilitybased risk classifications would be deemed to be discriminatory "eligibility criteria that screen out or tend to screen out" disabled individuals. ${ }^{118}$ But no court has held that all disability-based distinctions violate the $\mathrm{ADA}$ - such a holding would overhaul current insurance underwriting practices. Thus, as the text is unclear, it becomes necessary to consider the ADA's legislative history to understand the import of Title III as it relates to insurance.

The Senate Report discussing subparagraph (i) of the general antidiscrimination provision explains that policies and practices that "tend to" diminish disabled individuals' chances of participation-including facially neutral policies that "disproportionately screen[ ] out" disabled individuals-would be discriminatory. ${ }^{119}$ What the Senate meant by "screening out," however, is unclear in the context of insurance. For example, an insurer could screen out a disabled applicant by charging a higher premium or denying coverage because of the applicant's disability.

Regardless of what "screening out" means generally, the Senate Report's illustrations of the specific antidiscrimination provision indicate that Title III does not cover insurance underwriting decisions. The Senate Judiciary Report explains: "It [ ] would be a violation for [ ] an establishment to . . . identify unnecessarily the existence of a disability, as, for example, if the credit application of a department store were to inquire whether an individual has epilepsy, has ever [ ] been hospitalized for mental illness, or has [some] other disability." "120 From this example,

${ }^{112} 28$ CFR § 36.104 (1997) (emphasis added).

${ }^{118} 42$ USC \& 12182(b)(2)(A)(i).

${ }^{119} \mathrm{~S}$ Rep No 116 at 62 (cited in note 15). For example, a store policy requiring a driver's license to accompany all checks disproportionately screens out those disabled individuals unable to drive. Id.

${ }^{120}$ Id. The Report continued:

For example, it would be a violation for a grocery store to impose a rule that no blind persons would be allowed in the store, or for a drugstore to refuse to serve deaf peo- 
one could extrapolate that the denial of access-whether to a credit card, a grocery store, or a table-seating section-based on a disability is discriminatory, if done without adequate reason. One could also infer from the example that disabilities may not be used as proxies in areas unrelated to the disability. For example, a car dealership may refuse a blind person's request to take a test drive, but could not make a policy that blind people do not qualify for rebates. ${ }^{121}$ These illustrations, however, do not support the proposition that the specific antidiscrimination provision regulates the substance of the services provided. ${ }^{122}$

Thus, working through the text of the $\mathrm{ADA}$, and its legislative history where the text is ambiguous, it becomes clear that while Congress intended Title III to cover physical access to insurance offices, it did not intend to regulate the insurance plans offered therein.

\section{B. Defining the Scope of the Safe Harbor Provision}

Although this Comment has argued that its text and legislative history make clear that Title III does not regulate the terms of insurance, there is ample room for legitimate disagreement. Perhaps recognizing Title III's ambiguities, Congress inserted the "Construction" section into Title V. ${ }^{123}$ In it, Congress expressly provides employers, insurers, and administrators a safe harbor from Title III. ${ }^{124}$ However, this safe harbor provision raises two difficult questions regarding Title III's treatment of insurance. First, if Title III does not regulate the terms of insurance, why did Congress include a safe harbor provision? Second, if Title III

ple. ... Similarly, it can constitute a violation to impose criteria that limit the participation of people with disabilities, as for example, by requiring that individuals with Down's syndrome can only be seated at the counter, but not the table-seating section of a diner.

Id.

${ }^{121}$ These examples support the definition of "subterfuge" in Public Employees Retirement System of Ohio v Betts. See 492 US 158, 167 (1989).

${ }^{12}$ The Department of Justice regulations also reach this conclusion:

The purpose of the ADA's public accommodations requirements is to ensure accessibility to the goods offered by a public accommodation, not to alter the nature or mix of goods that the public accommodation has typically provided. In other words, a bookstore, for example, must make its facilities and sales operations accessible to individuals with disabilities, but is not required to stock Brailled or large print books. Similarly, a video store must make its facilities and rental operations accessible, but is not required to stock closed-captioned video tapes.

$28 \mathrm{CFR}$ pt 36 , app B, $\$ 36.307$ at 640 .

${ }^{223} 42$ USC $\S 12201$.

${ }^{22}$ Id § 12201(c). 
does regulate insurance, what effect does the safe harbor provision have on these claims?

After examining the provision in detail, this Comment answers these questions by concluding that the safe harbor provision serves as an interpretive device with which to clarify other provisions of the ADA. In particular, the safe harbor provision's exemption of insurance practices that are "not inconsistent with state law" makes clear that the broad language found in the general and specific antidiscrimination provisions should not be read to revamp current insurance practices. Thus, properly understood, the safe harbor provision reinforces the conclusion that Title III does not regulate the terms of insurance.

1. The purpose of the safe harbor provision.

Paragraphs (1) and (2) of the safe harbor provision, which protect insurance underwriting and risk classification procedures that are "based on or not inconsistent with state law," clearly exempt insurance practices that are consistent with state law. This reading finds support in the Senate Report, which sets out the purpose of the safe harbor provision:

Since there is some uncertainty over the possible interpretations of the language contained in titles I, II, and III as it applies to insurance, the Committee added [the safe harbor provision] to make it clear that this legislation will not disrupt the current nature of ... the insurance industry in sales, underwriting, pricing, administrative and other services, claims, and similar insurance related activities based on classification of risks as regulated by the States. . . . In sum, [the safe harbor provision] is intended to afford to insurers and employers the same opportunities they would enjoy in the absence of this legislation to design and administer insurance products and benefit plans in a manner that is consistent with basic principles of insurance risk classification. ${ }^{126}$

This state-compliance exemption for insurance reflects the Committee's belief that "[w]ithout such a clarification, this legislation could arguably find violative of its provisions any action taken by an insurer or employer which treats disabled persons differently under an insurance or benefit plan because they represent an in-

\footnotetext{
${ }^{125}$ Id $\S 12201$ (c)(1)-(2) (emphasis added).

${ }^{126} \mathrm{~S}$ Rep No 116 at 84-86 (cited in note 15) (emphasis added).
} 
creased hazard of death or illness."127 According to the Senate Report, then, the safe harbor provision clarifies that Title III's general and specific antidiscrimination provisions should not be read to cover the terms of insurance.

This interpretation of the safe harbor provision-immunizing insurance practices consistent with state law from the ADA-reinforces the earlier conclusion that Title III does not regulate insurance. Because a textual reading of the general and specific antidiscrimination provisions could dramatically change existing state insurance regulations, Congress inserted the safe harbor provision as an interpretive guide for the courts.

\section{Defining "subterfuge."}

This interpretation of the safe harbor provision has been obscured by different interpretations of "subterfuge." The safe harbor provision provides that compliance with "[p]aragraphs (1) [and] (2) . . . shall not be used as a subterfuge to evade the purposes of subchapters I and III of this chapter." ${ }^{128}$ Unfortunately, Congress did not define "subterfuge" in the $\mathrm{ADA}$, forcing courts to turn to Title V's legislative history to understand its meaning in the context of Title III.

In contrast to the Senate Report discussed above, the House Report's discussion of the safe harbor provision seems to evidence a different understanding of the safe harbor:

A plan may not refuse to insure, or refuse to continue to insure, or limit the amount, extent, or kind of coverage available to an individual, or charge a different rate for the same coverage solely because of a physical or mental impairment, except where the refusal, limitation, or rate differential is based on sound actuarial principles, or is related to actual or reasonably anticipated experience. For example, a blind person may not be denied coverage [based] on blindness independent of actuarial classification. Likewise, with respect to group health insurance coverage, an individual with a preexisting condition may [not] be denied coverage for ... illnesses or injuries unrelated to the [pre-existing] condition. ${ }^{129}$

The Cloutier court read this statement in the House Report to define the term "subterfuge." ${ }^{\text {"130 }}$ Under this reading, even if an un-

\footnotetext{
${ }^{127}$ Id at 86.

${ }^{128} 42$ USC $\S 12201$ (c).

${ }^{12}$ HR Rep No 485(III) at 71 (cited in note 101).

${ }^{130} 964 \mathrm{~F}$ Supp at 304. But see Doukas, $950 \mathrm{~F}$ Supp at 428 (reading the language as de-
} 
derwriting practice is consistent with state laws, it would be a subterfuge of the ADA if not based on actuarial data or reasonable experience. In so holding, the Cloutier court interpreted the "subterfuge" provision to create a substantive claim that can be brought in federal court under the ADA.

Cloutier's interpretation of the House Judiciary Report and the safe harbor's "subterfuge" language, however, has several flaws. Under this reading, what the safe harbor provision gives to the states it takes away with the word "subterfuge": rather than leave the state-regulated insurance industry intact, this interpretation adds a supplemental federal test. It is unlikely that Congress would undermine the express purpose of the safe harbor provision with one ambiguous word. It would be stranger still for Congress to insert this substantive federal insurance test in Title $\mathrm{V}$-a miscellaneous subchapter without a cause of action-rather than Title III itself. If Title III regulates insurance, then Title III should explain exactly how insurance should be regulated. However, because Title III's broad language cannot be taken literally in the insurance context, the Cloutier court may have been forced to define the cause of action in Title V. Thus, Cloutier's reasoning takes on a perverse circularity: it uses Title V, which expressly immunizes insurance practices from the ADA, to reinforce the conclusion that Title III covers insurance, and then applies the implicit requirements of Title $V$ to the case at hand.

A better reading of the House Report's language, in contrast to Cloutier's, would simply interpret it as an explication of paragraphs (1) and (2). The subterfuge provision informs the courts that "not inconsistent with state law" is tantamount to requiring that the insurer's practice be "based on sound actuarial principles" or "related to actual or reasonably anticipated experience." ${ }^{\text {"131 }}$ Indeed, the states had already required that insurance practices be based on actuarial data or reasonable experience before the ADA's enactment. Thus, even if Title III were read to cover insurance, it would go no further than existing state law.

Prior to the passage of the ADA, all fifty states ${ }^{132}$ had enacted statutes, based upon the NAIC's draft model legislation, prohibiting insurers from "[m]aking or permitting any unfair discrimination between individuals of the same class and of essentially

fining the safe harbor provision's language "not inconsistent with state law" rather than the "subterfuge" provision).

${ }^{131} \mathrm{~S}$ Rep No 116 at 85 (cited in note 15).

${ }^{132}$ See 4 NAIC Model Laws, Unfair Trade Practices Act at 880-15-880-18 (cited in note 6). 
the same hazard." 133 These statutes guarantee equality based on risk classification. For example, an insurer cannot differentiate between two individuals with similar actuarial risk profiles when the insurer writes a life insurance policy. ${ }^{134}$ Only twenty-four states, however, have implemented similar NAIC guidelines regarding mental and physical benefits in life and health insurance. ${ }^{135}$ These recommendations prohibit an insurer from "refusing to insure, or refusing to continue to insure, or limiting the amount, extent or kind of coverage available to an individual, or charging a different rate for the same coverage solely because of a physical or mental impairment, except where the refusal, limitation or rate differential is based on sound actuarial principles or is related to actual or reasonably anticipated experience."136

The NAIC guidelines' language is identical to the House Judiciary Report language. ${ }^{137}$ The similarity may suggest that Congress intended for the $\mathrm{ADA}$ to go beyond state law requirements. But as the NAIC guidelines expressly state, the guidelines serve only "to make clear that life and health insurers cannot classify individuals arbitrarily without a rational basis for each decision." 138 As the preexisting state statutes already prohibit discrimination between similar "hazards," the guidelines simply reassert the importance of this practice in regards to actuarially similar mental and physical disbilities. ${ }^{139}$ It follows that the identical language in the House Judiciary Report does not indicate that Congress intended to supplement existing state law. Compliance with state law means compliance with the ADA. Indeed, in its Report on the ADA, the Senate Committee on Labor and Human Resources explained: "The Committee does not intend that any provisions of this legislation should affect the way the insurance industry does business in accordance with the State laws and regulations under which it is regulated." ${ }^{140}$ As such, the

\footnotetext{
${ }^{123}$ Id at $880-4$.

${ }^{13}$ Id.

${ }^{125}$ See 4 NAIC Model Laws, Model Regulation on Unfair Discrimination in Life and Health at 887-3 (cited in note 6).

${ }^{106}$ Id at 887-1 \& 3 .

${ }^{137}$ See text accompanying note 129.

${ }^{138} 4$ NAIC Model Laws, Model Regulation on Unfair Discrimination in Life and Health Insurance at 887-1 § 2 (Drafting Note) (cited in note 6).

${ }^{200}$ This may explain why several states have not incorporated the guideline.

${ }^{100} \mathrm{~S}$ Rep No 116 at 84 (cited in note 15). The Report adds that Section 12201(c) "must be read to be consistent with [Section 12201(b)] pertaining to other Federal and State laws." Id at 85. Section 12201(b) provides: "Nothing in this chapter [of the Act] shall be construed to invalidate or limit the remedies, rights, and procedures of any Federal law or law of any State ... that provides greater or equal protection for the rights of individuals with disabilities than are afforded by this chapter [of the Act]." 42 USC $\S 12201(b)$.
} 
Committee adopted the prohibitions on "unfair discrimination among persons of the same class and equal expectation of life" found in "[v]irtually all States." "141

Once the state law requirements at the time of the ADA's enactment are understood, the plain meaning of paragraphs (1) and (2) of the safe harbor provision is clear: if an insurance practice is not inconsistent with state law (that is, it is based on sound actuarial data or reasonable experience), the ADA is not implicated. This reading may leave open the possibility that another title of the ADA that covers insurance, perhaps Title I, provides an alternative federal cause of action in which to bring state insurance claims. But, as argued above, Title III does not. ${ }^{142}$

However, the meaning of "subterfuge" remains unclear. Although Congress did not define "subterfuge" in the ADA, the Supreme Court has twice interpreted identical language in the Age Discrimination in Employment Act of $1967 .{ }^{143}$ The Court, referring to its meaning in "ordinary parlance" as well as its dictionary definition, defined "subterfuge" as a "scheme, plan, stratagem, or artifice of evasion." ${ }^{144}$ Reading an intent element into "subterfuge," the Court held that a benefit plan created before the ADEA was enacted could not be a "subterfuge," because the requisite intent was lacking. ${ }^{145}$ The Supreme Court's definition of "subterfuge" (in the McMann/Betts line of cases ${ }^{146}$ )—-with Congress's modifications as evinced in the legislative history-gives "subterfuge" independent meaning while maintaining the integrity of the safe harbor provision as a whole.

United Air Lines, Inc $v$ McMann ${ }^{147}$ required a showing of intent to discriminate under the ADEA and held that any plan adopted before the enactment of the ADEA could not be a subterfuge. ${ }^{148}$ However, the relevant legislative history makes clear that Congress did not want either of these results in the ADA. ${ }^{149}$ Thus,

\footnotetext{
${ }^{141} \mathrm{~S}$ Rep No 116 at 84 (cited in note 15).

${ }^{142}$ Again, this Comment does not address the possibility that claims relating to employer-offered insurance plans might be brought under Title I. See note 15.

${ }^{143} 29$ USC § 623(f)(2) (1976) ("It shall not be unlawful for an employer, employment agency, or labor organization ... to observe the terms of a bona fide employee benefit plan such as a retirement, pension, or insurance plan, which is not a subterfuge to evade the purposes of this chapter.”). The provision was subsequently amended. 29 USC $\S 623(f)(2)$ (1994).

${ }^{14}$ United Air Lines, Inc $v$ McMann, 434 US 192, 203 (1977). See also Betts, 492 US at 167-69.

${ }^{14}$ McMann, 434 US at 203.

${ }^{146}$ See note 90.

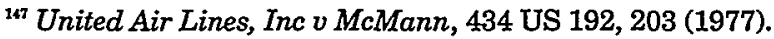

${ }^{14}$ Id.

${ }^{149}$ See HR Rep No 485(II) at 136 (cited in note 101) (Section 12201(c) may not be used
} 
as the Doukas court held, ${ }^{150}$ "subterfuge" should not be construed to require a showing of intent or to exempt benefit plans established before the ADA's enactment. These alterations do not limit, however, the Betts requirement that the subterfuge be of some other provision of the Act. ${ }^{151}$ Indeed, the examples regarding the safe harbor provision given in the House Judiciary Report are roughly consonant with this interpretation. ${ }^{152}$ For example, the Report explains that "a public accommodation cannot refuse to serve a person with a disability because its insurance company conditions coverage or rates on the absence of persons with disabilities. ${ }^{\text {} 153}$ In other words, even though the substance of the insurance plan may be protected under the safe harbor provision, it cannot be used to avoid the requirements in the specific antidiscrimination provision (which forbids criteria that "screen out" disabled individuals). Thus, Congress seems to have added the "subterfuge" clause to ensure that legitimate insurance classifications could not be used to justify discrimination in an unrelated area.

Thus, interpreting the safe harbor provision to protect insurance practices that are consistent with state law-while ensuring that this protection is not used to justify discrimination in an unrelated area-gives the provision an independent meaning consistent with the conclusion that Title III does not cover the terms of insurance.

\section{CONCLUSION}

Reading the ADA to cover the terms of insurance would mesh well with the overarching goal of equality for all disabled individuals. However, increased health care costs and the potential for unintended consequences make insurance a precarious area for implementing absolute equality. But whether or not Congress should change current state insurance law, it is clear that Congress did not do so in the ADA. Federal courts permitting Title III insurance claims to go forward risk carelessly balkanizing the

\footnotetext{
to evade Titles I, II, or III "regardless of the date an insurance plan or employer benefit plan was adopted."); 136 Cong Rec H 4624 (statement of Rep Edwards) (cited in note 100); 136 Cong Rec S 9697 (statement of Sen Kennedy) (cited in note 100) (explaining that "subterfuge" does not imply that a court must find malicious intent).

${ }^{150} 950$ F Supp at $430-32$.

${ }^{151}$ Betts, 492 US at 176.

${ }^{162}$ Like the Betts definition of "subterfuge," these examples forbid discrimination in an area of insurance unrelated to the actuarial risk of the disabled individual.

${ }^{15 s} \mathrm{HR}$ Rep No 485(III) at 56 (cited in note 101).
} 
state insurance regulatory regime without providing adequate guidance as to what the ADA requires. Moreover, these holdings misinterpret the scope of Title III and the purpose and meaning of the safe harbor provision. Instead, Title III should be read as its text and legislative history indicate-leaving to the states the continued duty of ensuring that insurance practices are based on actuarial risk classifications or reasonably anticipated experience. 